\title{
Biogeochemical evidence of anaerobic methane oxidation and anaerobic ammonium oxidation in a stratified lake using stable isotopes
}

\author{
Florian Einsiedl ${ }^{1}$, Anja Wunderlich ${ }^{1}$, Mathieu Sebilo ${ }^{2,3}$, Ömer K. Coskun ${ }^{4}$, William D. Orsi ${ }^{4,5}$, and Bernhard Mayer ${ }^{6}$ \\ ${ }^{1}$ Chair of Hydrogeology, Technical University of Munich, TUM Department of Civil, Geo and Environmental Engineering, \\ Arcisstrasse 21, 80333 Munich, Germany \\ ${ }^{2}$ Sorbonne Université, CNRS, IEES, 75005, Paris, France \\ ${ }^{3}$ Université de Pau et des Pays de l'Adour, E2S UPPA, IPRE, Institut des Sciences Analytiques et de Physico-Chimie pour \\ l'Environnement et les Matériaux, Pau, France \\ ${ }^{4}$ Department of Earth and Environmental Sciences, Paleontology and Geobiology, Ludwig-Maximilians-Universität \\ München, 80333 Munich, Germany \\ ${ }^{5}$ GeoBio-Center, Ludwig-Maximilians-Universität München, 80333 Munich, Germany \\ ${ }^{6}$ Department of Geoscience, University of Calgary, Calgary, Alberta, T2N 1N4, Canada
}

Correspondence: Florian Einsiedl (f.einsiedl@tum.de)

Received: 21 January 2020 - Discussion started: 6 February 2020

Revised: 24 August 2020 - Accepted: 26 August 2020 - Published: 23 October 2020

\begin{abstract}
Nitrate pollution of freshwaters and methane emissions into the atmosphere are crucial factors in deteriorating the quality of drinking water and in contributing to global climate change. The $n$-damo (nitrite-dependent anaerobic methane oxidation), nitrate-dependent anaerobic methane oxidation and the anaerobic oxidation of ammonium (anammox) represent two microbially mediated processes that can reduce nitrogen loading of aquatic ecosystems and associated methane emissions to the atmosphere. Here, we report vertical concentration and stable-isotope profiles of $\mathrm{CH}_{4}$, $\mathrm{NO}_{3}^{-}, \mathrm{NO}_{2}^{-}$, and $\mathrm{NH}_{4}^{+}$in the water column of Fohnsee (lake in southern Bavaria, Germany) that may indicate linkages between denitrification, anaerobic oxidation of methane (AOM), and anammox. At a water depth from 12 to $20 \mathrm{~m}$, a methane-nitrate transition zone (NMTZ) was observed, where $\delta^{13} \mathrm{C}$ values of methane and $\delta^{15} \mathrm{~N}$ and $\delta^{18} \mathrm{O}$ of dissolved nitrate markedly increased in concert with decreasing concentrations of methane and nitrate. These data patterns, together with the results of a simple 1-D diffusion model linked with a degradation term, show that the nonlinear methane concentration profile cannot be explained by diffusion and that microbial oxidation of methane coupled with denitrification under anaerobic conditions is the most parsi-
\end{abstract}

monious explanation for these data trends. In the methane zone at the bottom of the NMTZ (20 to $22 \mathrm{~m}$ ) $\delta^{15} \mathrm{~N}$ of ammonium increased by $4 \%$, while ammonium concentrations decreased. In addition, a strong ${ }^{15} \mathrm{~N}$ enrichment of dissolved nitrate was observed at a water depth of $20 \mathrm{~m}$, suggesting that anammox is occurring together with denitrification. The conversion of nitrite to $\mathrm{N}_{2}$ and nitrate during anammox is associated with an inverse $\mathrm{N}$ isotope fractionation and may explain the observed increasing offset $\left(\Delta \delta^{15} \mathrm{~N}\right)$ of $26 \%$ o between $\delta^{15} \mathrm{~N}$ values of dissolved nitrate and nitrite at a water depth of $20 \mathrm{~m}$ compared to the $\Delta \delta^{15} \mathrm{~N}_{\text {nitrate-nitrite }}$ of $11 \%$ obtained in the NMTZ at a water depth between 16 and $18 \mathrm{~m}$. The associated methane concentration and stable-isotope profiles indicate that some of the denitrification may be coupled to AOM, an observation supported by an increased concentration of bacteria known to be involved in n-damo/denitrification with AOM (NC10 and Crenothrix) and anammox ("Candidatus Anammoximicrobium") whose concentrations were highest in the methane and ammonium oxidation zones, respectively. This study shows the potential for a coupling of microbially mediated nitrate-dependent methane oxidation with anammox in stratified freshwater ecosystems, which may be im- 
portant for affecting both methane emissions and nitrogen concentrations in lakes.

\section{Introduction}

Methane is a more potent greenhouse gas than $\mathrm{CO}_{2}$ and is responsible for $20 \%$ of global warming (IPCC Working Group I, 2001). Bastviken et al. (2004) have shown that lacustrine ecosystems may be responsible for $6-16 \%$ of natural methane emissions. However, the variability in methane emissions and the lack of knowledge about their main environmental controls contribute to large uncertainties about the global $\mathrm{CH}_{4}$ budget (Sabrekov et al., 2017).

Methane is abundantly formed in anaerobic lake sediments by methanogenesis (Borrel et al., 2011; Conrad et al., 2007; Norði et al., 2013) and diffuses upwards through the water column toward the oxycline of often nitrate-containing seasonally stratified lakes. With the discovery of the anaerobic oxidation of methane (AOM) coupled to nitrate or nitrite reduction more than 10 years ago a new process was suggested that has the potential to reduce emissions of greenhouse gases of lacustrine environments by oxidizing $\mathrm{CH}_{4}$ to $\mathrm{CO}_{2}$ under anoxic conditions (Ettwig et al., 2010; Haroon et al., 2013; Raghoebarsing et al., 2006). Under controlled laboratory conditions, experiments have shown that $n$ damo (nitrite-dependent anaerobic methane oxidation) bacteria that are members of the candidate phylum $\mathrm{NC10}$ use nitrite for the anaerobic oxidation of methane (Ettwig et al., 2010), while archaea such as ANME-2d prefer nitrate as an electron acceptor (Haroon et al., 2013). Evidence of archaeal AOM coupled with bacterial denitrification was first reported from culture experiments with two microorganisms, "Candidatus Methylomirabilis oxyfera", which belongs to the phylum $\mathrm{NC} 10$ and reduces nitrite to $\mathrm{N}_{2}$, and ANME-2d lineage that uses methane to reduce nitrate to nitrite (Raghoebarsing et al., 2006).

Filamentous methane-oxidizing bacteria related to the genus Crenothrix (Gammaproteobacteria) also use nitrate as a terminal electron acceptor (Kits et al., 2015; Naqvi et al., 2018; Oswald et al., 2017). Therefore, Crenothrix may act as a driver for methane oxidation in nitrate-containing stratified lakes, where environmental and redox conditions can often change over seasonal periods. A few environmental studies have documented the presence of NC10-like bacteria in lake sediments, which are thought to have a similar metabolism to $\mathrm{Ca}$. M. oxyfera. Via micro-sensor measurements and molecular biological analysis it was postulated that $\mathrm{Ca}$. M. oxyfera is responsible for $\mathrm{n}$-damo in the sediments of Lake Constance (Deutzmann et al., 2014), while others found some evidence of n-damo in the sediments of a lake in Japan (Kojima et al., 2012).

It has been speculated that denitrification can co-occur with anammox at oxic-anoxic interfaces (Strous and Jetten,
2004; Thauer and Shima, 2008). In the late 1980s, microorganisms driving the anammox reaction were first discovered in a wastewater pilot plant (Francis et al., 2007; Mulder et al., 1995). Subsequently, the significance of the anammox process in the nitrogen cycle of freshwater systems was shown in numerous studies (e.g., Schubert et al., 2006), and it was suggested that the process is of key environmental significance (Kuypers et al., 2003). The coexistence of heterotrophic denitrification, $n$-damo, and anammox was clearly demonstrated in bioreactor studies supplied with nitrate, methane, and ammonium (Haroon et al., 2013; Hu et al., 2015; Luesken et al., 2011; Shi et al., 2013).

By comparison, the number of studies demonstrating the co-occurrence of n-damo and anammox processes in natural aquatic environments is limited (e.g., Shen et al., 2014; Zhu et al., 2018). More information is needed on the connection of these processes in the natural environment, in order to obtain an accurate estimation of methane fluxes to the atmosphere and to identify the factors driving and limiting the reduction of nitrate and its intermediates in lacustrine environments. Stable-isotope fractionation has often been used to identify microbial transformation processes affecting nitrogen and carbon, including denitrification and AOM (e.g., Wunderlich et al., 2012). Recently, Granger and Wankel (2016) showed that displaying the isotope compositions of nitrate in a 2-D isotope plot $\left(\delta^{18} \mathrm{O} / \delta^{15} \mathrm{~N}\right)$ enables the distinction between denitrification and anammox. In addition, aerobic and anaerobic methane oxidation has often been documented by increasing $\delta^{13} \mathrm{C}$ values in the remaining methane (Eller et al., 2005; Feisthauer et al., 2011). However, the separation of aerobic and anaerobic oxidation of methane based on calculated isotope enrichment factors of methane may fall short because of overlapping carbon isotope enrichment factors (Feisthauer et al., 2011).

Here we report chemical and isotopic evidence together with quantitative PCR (qPCR) and high-throughput Illumina sequencing of $16 \mathrm{~S}$ rRNA genes to provide evidence for the co-occurrence of $n$-damo/denitrification with AOM and anammox in a natural freshwater habitat. We also applied a simple 1-D diffusion model and coupled the diffusion model with a degradation term to test the hypothesis that methane oxidation with nitrate was microbially mediated. Our findings show that microbially mediated linkages between $\mathrm{n}$ damo/denitrification with AOM and anammox have the potential to constitute an important sink of both dissolved nitrogen $\left(\mathrm{NO}_{3}^{-}, \mathrm{NO}_{2}^{-}\right.$, and $\left.\mathrm{NH}_{4}^{+}\right)$and methane $\left(\mathrm{CH}_{4}\right)$ in stratified freshwater ecosystems.

\section{Material and methods}

\subsection{Field site}

The Osterseen are located in southern Germany and consist of a series of lakes that are hydrologically connected (Braig 
et al., 2010). The chain of lakes was formed after the rapid disintegration of the last ice sheet at the end of the Pleistocene. Fohnsee, which was sampled in 2016, is one of the Osterseen. The lake is circa $22 \mathrm{~m}$ deep, fed by groundwater, and stratified during summer with an oxic zone (epilimnion) near the surface and an anoxic redox zone (hypolimnion) below a water depth of approximately $12 \mathrm{~m}$.

\subsection{Sampling}

A field campaign at Fohnsee was performed in summer 2016 to obtain depth-resolved water samples throughout the water column of the lake to a depth of $22 \mathrm{~m}$. During the field campaign a submersible probe with sensors for temperature and oxygen content was used. Dissolved oxygen concentrations and lake water temperatures with a depth resolution of $1 \mathrm{~m}$ were measured on site. Water samples were taken with a discrete $2 \mathrm{~L}$ sampling unit ("Ruttner bottle") with a depth resolution between 1 and $2 \mathrm{~m}$. The detection limit of the oxygen sensor (FDO 925, WTW, Xylem, Germany) was $<0.625 \mu \mathrm{molL}^{-1}$; the analytical error was $0.5 \%$ of the measured value for oxygen. In addition to the in situ measurements, samples for the laboratory-based measurement of major anion and cation concentrations, and water isotopes $\left(\delta^{2} \mathrm{H}\right.$ and $\left.\delta^{18} \mathrm{O}\right)$ were field-filtered with $0.2 \mu \mathrm{m}$ PES filters and stored in airtight $1.5 \mathrm{~mL}$ glass vials. Samples for isotope analysis of nitrite $\left(\delta^{15} \mathrm{~N}\right)$, nitrate $\left(\delta^{15} \mathrm{~N}\right.$ and $\left.\delta^{18} \mathrm{O}\right)$, and ammonium $\left(\delta^{15} \mathrm{~N}\right)$ were field-filtered with $0.2 \mu \mathrm{m}$ PES filters and stored in PE vials. Isotope samples were frozen at $-23^{\circ} \mathrm{C}$ until processing. Samples for analysis of DOC (dissolved organic carbon) concentrations were collected in $50 \mathrm{~mL}$ glass bottles, filtered with $0.45 \mu \mathrm{m}$ PVDF filters and measured immediately in the laboratory. Samples for the concentrations and isotope analysis of methane $\left(\delta^{13} \mathrm{C}\right)$ were transferred into $200 \mathrm{~mL}$ glass vials without headspace and sealed with crimped butyl stoppers. Samples for molecularbiological investigations were collected in $2 \mathrm{~L}$ sterile glass bottles. Subsequently the $2 \mathrm{~L}$ water samples were divided into two $1 \mathrm{~L}$ samples for replicate measurements, and each sample was filtered in the laboratory using a $0.2 \mu \mathrm{m}$ sterile filter. The filter including the microbial biomass was kept frozen at $-23^{\circ} \mathrm{C}$ prior to analysis.

\subsection{Determination of water chemistry and DOC}

The samples were analyzed with ion chromatography for concentrations of nitrate, nitrite, ammonium, and sulfate. The analyses were performed in triplicate using two parallel Thermo Scientific ICS1100 instruments, one with CS12A (cations) and the other with AS9-HC (anions) columns. Values are reported as mean values $(n=3)$ with an uncertainty of less than $10 \%$. The detection limits are < $0.008 \mathrm{mmolL}^{-1}$ for nitrate, $<0.007 \mathrm{mmolL}^{-1}$ for nitrite, and $<0.005 \mathrm{mmolL}^{-1}$ for ammonium.
DOC concentrations were determined by lowering the $\mathrm{pH}$ of the samples to remove inorganic carbon and subsequent spectral analysis of $\mathrm{CO}_{2}$ after combustion (Analytic Jena Multi N/C 3100) with a measurement uncertainty of $\pm 5 \%$ and a detection limit of $0.5 \mathrm{mg} \mathrm{L}^{-1}$.

\subsection{Analytical model for evaluating methane diffusion and the potential of micro-aerobic oxidation of methane in the water column}

For the 1-D diffusion model, a semi-infinite system was assumed where the lower boundary (at $z=0$ ) is kept at a constant input concentration $C_{0}$, and the initial concentration throughout the system is zero. The following formula (Eq. 1) from Crank (1975) represents an analytical solution, which was used to determine the methane concentration as a function of depth (resolved in $0.1 \mathrm{~m}$ intervals) along the $10 \mathrm{~m}$ long water column below the oxycline at time $t$ :

$C(z, t)=C_{0} \operatorname{erfc} \frac{z}{2 \sqrt{ }\left(K_{z} t\right)}$,

where $C\left[\mu \mathrm{mol} \mathrm{L}{ }^{-1}\right]$ is the methane concentration in the water column as a function of distance (depth) $z$ and time; $C_{0}\left[\mu \mathrm{mol} \mathrm{L}^{-1}\right]$ is the constant concentration of methane at the lower boundary, located at a depth of $22 \mathrm{~m}$ below the lake surface (bottom of the water column); and $K_{z}\left[\mathrm{~m}^{2} \mathrm{~d}^{-1}\right]$ represents the turbulent diffusion coefficient for methane in water. For modeling, time $t$ was set to $90 \mathrm{~d}$. This corresponds to the period where stagnant conditions for lake water are assumed to prevail (no advective mixing) so that methane is transported within the water column by diffusion only. For methane a turbulent diffusion coefficient of $K_{z}=1.2 \times 10^{-6} \mathrm{~m}^{2} \mathrm{~s}^{-1}$, corresponding to $0.1 \mathrm{~m}^{2} \mathrm{~d}^{-1}$, was calculated for Fohnsee according to Wenk et al. (2013) and Bless et al. (2014) with the system-specific parameter $a_{0}$ of $0.000343 \mathrm{~cm}^{2} \mathrm{~s}^{-2}$. The $K_{z}$ value is at the lower range typically applied for methane flux calculations and modeling $\left(0.1-2.1 \mathrm{~m}^{2} \mathrm{~d}^{-1}\right)$ at stratified lakes such as at Rotsee and Lake Lugano (Oswald et al., 2015; Wenk et al., 2013).

If the diffusing substance is microbially degraded or immobilized, the differential equation for diffusion needs to be extended by additional reaction terms. If first-order degradation is considered, an analytical solution is also available from Crank (1975), which was used for 1-D modeling of methane diffusion and degradation (Eq. 2):

$$
\begin{aligned}
C(z, t) & =\frac{C_{0}}{2} \exp \left(-z \sqrt{k / K_{z}}\right) \operatorname{erfc}\left(\frac{z}{2 \sqrt{K_{z} t}}-\sqrt{k t}\right) \\
& +\frac{C_{0}}{2} \exp \left(z \sqrt{k / K_{z}}\right) \operatorname{erfc}\left(\frac{z}{2 \sqrt{K_{z} t}}+\sqrt{k t}\right),
\end{aligned}
$$

where $k$ is the first-order degradation rate constant $\left(\mathrm{d}^{-1}\right)$. Here we used the $k$ value as fitting parameter and compared it to literature data from Roland et al. (2017). If the argument $k t$ in Eq. (2) is large enough so that erfc is approaching 2 at 
the left-hand side and 0 at the right-hand side, Eq. (3) simplifies as follows (Crank, 1975):

$C=C_{0} \exp \left(-x \sqrt{k / K_{z}}\right)$.

\subsection{Measurement of stable-isotope ratios}

The natural abundance stable-isotope ratios of nitrogen $\left({ }^{15} \mathrm{~N} /{ }^{14} \mathrm{~N}\right)$ in $\mathrm{NH}_{4}^{+}, \mathrm{NO}_{3}^{-}$, and $\mathrm{NO}_{2}^{-}$and oxygen $\left({ }^{18} \mathrm{O} /{ }^{16} \mathrm{O}\right)$ in $\mathrm{NO}_{3}^{-}$and $\mathrm{NO}_{2}^{-}$as well as carbon isotope ratios $\left({ }^{13} \mathrm{C} /{ }^{12} \mathrm{C}\right)$ of methane constitute a powerful tool to identify biogeochemical transformation processes involving these compounds. During AOM and denitrification the lighter isotopes $\left({ }^{12} \mathrm{C},{ }^{14} \mathrm{~N}\right.$, and $\left.{ }^{16} \mathrm{O}\right)$ react preferentially, leading to an enrichment of the heavier isotopes $\left({ }^{13} \mathrm{C},{ }^{15} \mathrm{~N}\right.$, and $\left.{ }^{18} \mathrm{O}\right)$ in the residual substrate pool $\left(\mathrm{CH}_{4}, \mathrm{NO}_{3}^{-}\right.$, and $\left.\mathrm{NH}_{4}^{+}\right)$and an enrichment of the lighter isotopes in the newly formed products $\mathrm{CO}_{2}, \mathrm{NO}_{2}^{-}$, and $\mathrm{N}_{2}$. Stable-isotope ratios of $\mathrm{C}, \mathrm{N}$, and $\mathrm{O}$ are reported using the conventional delta $(\delta)$ notation expressed as $\delta=\left(\frac{R_{\text {sample }}}{R_{\text {standard }}}-1\right)\left[\%\right.$ ], where $R_{\text {sample }}$ and $R_{\text {standard }}$ are the ratios of heavy vs. light isotopes in the sample and an international standard, respectively.

\subsubsection{Water isotope composition}

Hydrogen and oxygen isotope ratios of water $\left({ }^{18} \mathrm{O} /{ }^{16} \mathrm{O}\right.$ and ${ }^{2} \mathrm{H} /{ }^{1} \mathrm{H}$ ) were analyzed by off-axis laser spectroscopy using a water analyzer (Los Gatos Instruments IWA-45EP) with a precision of $0.1 \%$ for $\delta^{18} \mathrm{O}$ and $0.5 \%$ for $\delta^{2} \mathrm{H}$ and are reported with respect to Vienna Standard Mean Ocean Water (V-SMOW).

\subsubsection{Isotope compositions of nitrate, nitrite, and ammonium}

$\delta^{15} \mathrm{~N}$ and $\delta^{18} \mathrm{O}$ values of nitrate and $\delta^{15} \mathrm{~N}$ values of nitrite and ammonium were obtained by the production of $\mathrm{N}_{2} \mathrm{O}$ following modified protocols of procedures reported by McIlvin and Altabet (2005), Semaoune et al. (2012), and Zhang et al. (2007), respectively. Nitrite was converted to $\mathrm{N}_{2} \mathrm{O}$ using acetic acid buffer sodium azide, similar to the analysis of nitrate. In order to ensure the proper reduction of nitrite to $\mathrm{N}_{2} \mathrm{O}$, in addition to the samples, internal laboratory standards for $\mathrm{KNO}_{2}$ were analyzed in each batch $\left(\mathrm{Lb} 1, \delta^{15} \mathrm{~N}=-63 \%\right.$, and $\mathrm{Lb} 2, \delta^{15} \mathrm{~N}=+2.7 \%$ ). Corrections of the raw $\delta^{15} \mathrm{~N}$ values were made based on the known values of the nitrate and nitrite standards. In a second aliquot of the sample, nitrate was first reduced to nitrite in an activated column of cadmium and the mixture of both nitrate and nitrite was reduced to $\mathrm{N}_{2} \mathrm{O}$ via azide. The yield of conversion was better than $95 \%$. Nitrogen isotope ratios of nitrate were calculated by measuring nitrite alone as well as the mixture of nitrite and nitrate in a sample and using an inverse mixing calculation to determine the isotopic ratios of nitrate alone. For $\delta^{18} \mathrm{O}$ values of nitrate we performed a mass-weighted isotope mass balance calculation assuming that at a $\mathrm{pH}$ of 7 the $\delta^{18} \mathrm{O}$ of nitrite is in equilibrium with water with a value close to $+4 \%$ o (Casciotti et al., 2007). Ammonium was oxidized to nitrite using hypobromite $\left(\mathrm{BrO}^{-}\right)$. The nitrite produced from ammonium oxidation was then transformed into dissolved $\mathrm{N}_{2} \mathrm{O}$ by buffered azide solution for subsequent analysis. The isotope compositions of all $\mathrm{N}_{2} \mathrm{O}$ samples were measured with an isotope ratio mass spectrometer (IRMS; Delta V Plus, Thermo Scientific, Bremen, Germany) in continuous-flow mode with a purge-and-trap system coupled with a Finnigan GasBench II system (Thermo Scientific, Bremen, Germany). Results are reported in the internationally accepted delta notation in units of per mil with respect to the standards AIR for $\delta^{15} \mathrm{~N}$ and V-SMOW for $\delta^{18} \mathrm{O}$. Ammonium, nitrate, and nitrite reference materials subject to the same analytical procedures were used to calibrate the isotopic composition of $\mathrm{N}_{2} \mathrm{O}$. The standards USGS25, $\delta^{15} \mathrm{~N}=-30.4 \%$; IAEA-N $1, \delta^{15} \mathrm{~N}=0.4 \%$; IAEA-N2, $\delta^{15} \mathrm{~N}=20.3 \%$; and IAEA-305, $\delta^{15} \mathrm{~N}=39.8 \%$, were used for ammonium reference materials, and USGS34, $\delta^{15} \mathrm{~N}=-1.8 \%$ o, $\delta^{18} \mathrm{O}=$ $-27.9 \%$; USGS35, $\delta^{15} \mathrm{~N}=+2.7 \%$ o, $\delta^{18} \mathrm{O}=+57.5 \%$; and USGS32, $\delta^{15} \mathrm{~N}=+180 \%, \delta^{18} \mathrm{O}=+25.7 \%$, were used to calibrate nitrate measurements. Laboratory nitrite standards $\mathrm{Lb} 1, \delta^{15} \mathrm{~N}=-63 \%$, and $\mathrm{Lb} 2, \delta^{15} \mathrm{~N}=+2.7 \%$, were used to calibrate nitrite isotope analyses. The precision for $\delta^{15} \mathrm{~N}$ values of ammonium was $\pm 0.3 \%$. The precision for $\delta^{15} \mathrm{~N}$ values of nitrate and nitrite was $\pm 0.5 \%$, and for $\delta^{18} \mathrm{O}$ of nitrate it was $\pm 0.8 \%$.

\subsubsection{Concentrations and carbon isotope ratios of dissolved methane}

The concentrations and carbon isotope ratios of dissolved methane in the lake water samples were determined from the same bottle using the static headspace equilibrium technique (EPA, 2002) where $10 \%$ of the water sample in the capped bottles was replaced with helium followed by outgassing of the dissolved gases in the water sample into the headspace for $1 \mathrm{~h}$ at $25^{\circ} \mathrm{C}$. Subsequently, the concentration of methane in the headspace was determined by manual injection of $>2 \mathrm{~mL}$ of gas into a gas chromatograph (Bruker 450 ) with a measurement uncertainty of $< \pm 5 \%$. The concentration of dissolved methane in the water samples (in $\mathrm{mgL}^{-1}$ ) was subsequently determined using Henry's law (EPA, 2002).

The carbon isotope ratios of methane in the headspace of the same samples were analyzed on a ThermoFisher MAT 253 IRMS coupled to a Trace GC Ultra + GC Isolink (ThermoFisher) after manual injection of $<1 \mathrm{~mL}$ of gas. We assumed negligible $\mathrm{C}$ isotope fractionation between dissolved methane and methane in the headspace (e.g., Feux, 1980) and therefore report the measured $\delta^{13} \mathrm{C}$ values for headspace methane. Carbon isotope ratios of methane are reported in the standard delta notation in units of per mil relative to the VPDB standard. Instrument stability and linearity was 
ensured by daily measurements of an in-house methane mix of $5 \% \mathrm{CH}_{4}$ (balance helium). Carbon isotope analyses of methane were standardized by measurements of Isometric Instruments (Victoria, BC, Canada) gases containing methane with known $\delta^{13} \mathrm{C}$ values including the following: B-iso1 $\left(\delta^{13} \mathrm{C}=-54.5 \%\right.$, $\delta^{2} \mathrm{H}=-266 \%$ ) , L-iso1 $\left(\delta^{13} \mathrm{C}=\right.$ $-66.5 \%$ o, $\delta^{2} \mathrm{H}=-171 \%$, and $\mathrm{H}$-iso1 $\left(\delta^{13} \mathrm{C}=-23.9 \%\right.$, $\delta^{2} \mathrm{H}=-156 \%$ ). The precision for carbon isotope analyses on dissolved methane was better than $\pm 0.5 \%$ o.

\subsection{DNA extraction}

Microbial biomass was collected on $0.22 \mu \mathrm{m}$ cellulose acetate filters (Corning Inc., NY, USA) in the laboratory after sampling and stored frozen on dry ice and later at $-23{ }^{\circ} \mathrm{C}$ until DNA extraction. Total DNA for groundwater microbial community analysis was extracted from frozen filters as previously described (Brielmann et al., 2009).

\subsection{Quantitative gene sequencing}

Quantitative PCR (qPCR) was performed using the customprimer dual-indexed approach that is commonly applied in microbial ecology community analyses (Kozich et al., 2013) and targets the V4 hypervariable region of the $16 \mathrm{~S}$ rRNA gene using updated $16 \mathrm{~S}$ rRNA gene primers 515F/806R (515F: 5'-GTGYCAGCMGCCGCGGTAA-3', 806R: GGACTACNVGGGTWTCTAAT) as described previously (Coskun et al., 2018). These "universal" primers cover all major groups of bacteria and archaea, and have the "Y" ambiguity code insertion into the $515 \mathrm{~F}$ forward primer to increase the coverage of archaea (Parada et al., 2016). qPCR reactions were prepared using an automated liquid handler (pipetting robot); the EpMotion 5070 (Eppendorf) was used to set up all qPCR reactions and standard curves. The efficiency values of the qPCR were $<90 \%$ with $R^{2}$ values $>$ $0.95 \%$. qPCR was performed using white 96-well plates. The technical variability of $16 \mathrm{~S}$ rRNA gene qPCR measurements was determined to be consistently $<5 \%$ under the EpMotion 5070.

Barcoded V4 hypervariable regions of the amplified 16S rRNA genes from the qPCR were sequenced on an Illumina MiniSeq following an established protocol (Pichler et al., 2018). This yielded a total of $>2000000$ raw sequencing reads that were then subjected to quality control. In order to quality-control the operational taxonomic unit (OTU) picking algorithm for the data, we also sequenced a "mock community" alongside our environmental samples. The mock communities contained a defined number of species $(n=18)$ all containing $16 \mathrm{~S}$ rRNA genes $>3 \%$ difference (Pichler et al., 2018). USEARCH version 10.0.240 was used for quality control and OTU picking (Edgar, 2013); OTUs were clustered at $97 \%$ sequence identity. The taxonomic relationship of OTU representative sequences was identified by BLASTn searches against the SILVA database (http://www.arb-silva. de, last access: June 2019) version 132. To identify contaminants, 16S rRNA genes from extraction blanks and dust samples from the lab were also sequenced. These $16 \mathrm{~S}$ rRNA gene sequences from contaminants were used to identify any contaminating bacteria in our samples. All OTUs containing sequences from these "contaminant" samples $(<5 \%$ of total $)$ were removed prior to downstream analysis.

The qPCR and sequencing data were then used to quantify the abundance of individual 16S rRNA genes per OTU across the sampled water column, in the different biogeochemical zones. The fractional abundance (percent total sequences per sample) of each $16 \mathrm{~S}$ OTU was multiplied by the total number of $16 \mathrm{~S}$ rRNA genes per sample. This provided quantitative gene abundance per OTU, converting the relative abundance in the $16 \mathrm{~S}$ rRNA gene libraries into quantitative values.

\section{Results}

\subsection{Temperature, sulfate, and DOC depth profiles}

DOC concentrations were highest at the lake surface with concentrations of nearly $5 \mathrm{mg} \mathrm{L}^{-1}$ and decreased to values of around $3 \mathrm{mg} \mathrm{L}^{-1}$ at the lake bottom (Fig. 1a). The lake water surface temperature was $18^{\circ} \mathrm{C}$ and decreased to $5^{\circ} \mathrm{C}$ at a water depth of around $12 \mathrm{~m}$ (Fig. 1a). As a result, summer warming resulted in a stratification of Fohnsee with the development of an anoxic hypolimnion between 12 and $22 \mathrm{~m}$ from around May to September with a constant temperature of $5^{\circ} \mathrm{C}$.

Sulfate concentrations were $0.1 \mathrm{mmolL}^{-1}$ in the epilimnion and remained unchanged within the analytical uncertainty in the anoxic hypolimnion (Fig. 1a). Sulfate concentrations only decreased from a mean value of around 0.1 to $0.07 \mathrm{mmol} \mathrm{L}^{-1}$ very close to the water/lake-sediment interface.

\subsection{Depth profiles of $\mathrm{O}_{2}, \mathrm{NO}_{x}^{-}, \mathrm{NH}_{4}^{+}$, and stable water and nitrogen isotopes}

Aerobic conditions were prevalent within the epilimnion with a steep oxygen concentration gradient from $>0.28 \mathrm{mmol} \mathrm{L}^{-1}$ at the surface towards $<0.625 \mu \mathrm{mol} \mathrm{L}-1$ below $12 \mathrm{~m}$ (Fig. 1b). The average concentration of nitrate in the epilimnion was $0.21 \mathrm{mmol} \mathrm{L}^{-1}$ (Fig. 1b). Below $12 \mathrm{~m}$, in the nitrate-methane transition zone (NMTZ), dissolved oxygen concentrations decreased below detection $\left(<0.625 \mu \mathrm{mol} \mathrm{L}{ }^{-1}\right)$, and at a water depth of $21 \mathrm{~m}$ nitrate concentrations decreased to $<0.008 \mathrm{mmol} \mathrm{L}^{-1}$, while nitrite concentrations peaked at $0.02 \mathrm{mmol} \mathrm{L}^{-1}$ at a water depth of $20 \mathrm{~m}$. Ammonium concentrations decreased from around $0.06 \mathrm{mmol} \mathrm{L}^{-1}$ at the lake bottom to the oxycline and were below detection $\left(<0.005 \mathrm{mmol} \mathrm{L}^{-1}\right)$ above a water depth of $12 \mathrm{~m}$ (Fig. 1b).

$\delta^{15} \mathrm{~N}$ and $\delta^{18} \mathrm{O}$ values of dissolved nitrate increased in the anoxic water column $\left(\mathrm{O}_{2}\right.$ concentration $<0.0 .625 \mu \mathrm{mol} \mathrm{L}^{-1}$ 

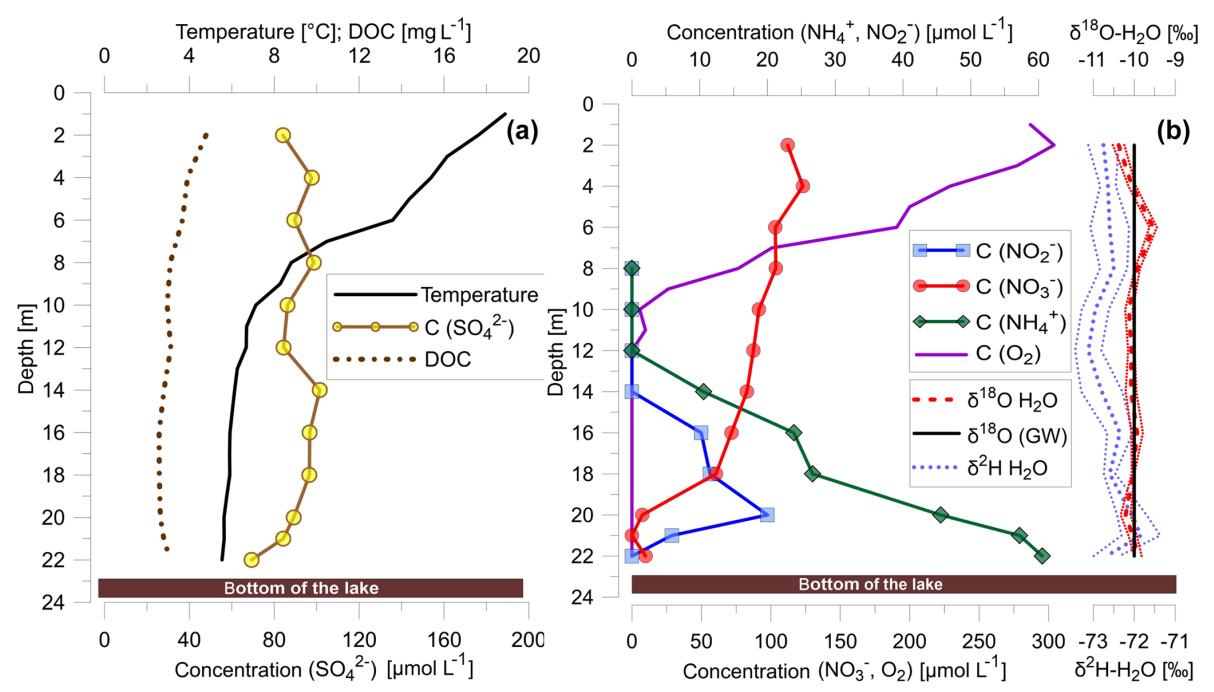

Figure 1. (a) Temperature profile and vertical distribution of concentrations of DOC and sulfate; (b) concentrations of dissolved nitrate, nitrite, ammonium and dissolved oxygen as well as $\delta^{2} \mathrm{H}$ and $\delta^{18} \mathrm{O}$ values of lake water and $\delta^{18} \mathrm{O}$ value of groundwater (GW).

at a water depth below $12 \mathrm{~m}$ ) of the lake from 6.7 to $45.4 \%$ for $\delta^{15} \mathrm{~N}$ and from around 1.7 to $23.6 \%$ for $\delta^{18} \mathrm{O}$ (Fig. 2c). Simultaneously, $\delta^{15} \mathrm{~N}$ of nitrite increased from 0.1 to $18.7 \%$ \% concurrently with increasing $\delta^{15} \mathrm{~N}$ values of nitrate (Fig. 2c). The $\delta^{15} \mathrm{~N}$ values of ammonium increased from $7.9 \%$ at the lake bottom to $11.6 \%$ near the NMTZ, while simultaneously decreasing ammonium concentrations from 0.060 to $0.045 \mathrm{mmol} \mathrm{L}^{-1}$ were observed (Fig. 2). The oxygen isotope ratios of lake water varied between -10.4 and $-9.5 \%$ for $\delta^{18} \mathrm{O} . \delta^{2} \mathrm{H}$ values were $-73.0 \%$. In the aquifer the $\delta^{18} \mathrm{O}$ value was very close to $-10 \%$ (Fig. 1b), supporting earlier findings that lake water is mainly derived from groundwater (Braig et al., 2010).

\subsection{Depth profile of methane concentrations and C isotope ratios}

Concentrations of dissolved methane were highest in the methane zone (from 22 to $20 \mathrm{~m}$ ) near the lake bottom, with concentrations of $0.16 \mathrm{mmol} \mathrm{L}^{-1}$, but decreased to concentrations below the detection limit towards the NMTZ (from 20 to $12 \mathrm{~m}$ ). With decreasing methane concentrations, $\delta^{13} \mathrm{C}_{\mathrm{CH} 4}$ values increased from $-72 \%$ at the lake bottom to $-39 \%$ at a water depth of $18 \mathrm{~m}$ in the NMTZ (Fig. 2b). Above a water depth of $18 \mathrm{~m}$, methane concentrations were too low for stable-isotope analyses. The steepest countergradients of nitrate and methane concentrations were observed at a water depth between 18 and $21 \mathrm{~m}$ (Fig. 2a and b), exactly where nitrite concentrations peaked (Fig. 2a).

\subsection{Microbial community distribution in the water column of Fohnsee}

To identify the microbial taxa potentially responsible for mediating the $\mathrm{N}$ and $\mathrm{C}$ cycling processes identified in the chemical and stable-isotope profiles, we performed highthroughput Illumina sequencing of the V4 hypervariable region of the 16S rRNA genes together with qPCR at selected depths throughout the water column corresponding to the distinct geochemical zones identified in the vertical chemical profiles. Analysis of similarity (ANOSIM) performed on the data revealed that significantly $(R: 0.57, P=0.002)$ different microbial communities inhabited four geochemical zones in the water column: the oxic lake water $(6 \mathrm{~m})$; the upper NMTZ (12-14 m); the lower NMTZ (16-18 m); and a methane-rich zone near the lake bottom, where nitrate and nitrite concentrations decreased towards the detection limit (20-22 m) (Figs. 2a and 3). The differences in the communities are attributed to a decrease in the Verrucomicrobia and Actinobacteria with depth, and a large increase in the relative abundance of Gammaproteobacteria at a water depth of $22 \mathrm{~m}$ (Fig. 3b). While present at a lower relative abundance, Epsilonproteobacteria, Deltaproteobacteria, and Bacteroidetes also increased with increasing depth below the oxycline (Fig. 3b).

The relative abundance of populations (operational taxonomic units sharing $97 \%$ sequence identity) was converted into quantitative terms by multiplying the fractional (relative) abundance of the populations against the total number of 16S rRNA gene copies per sample determined by qPCR. This revealed a peak in microbial abundance just below the oxic-anoxic transition zone between 12 and $14 \mathrm{~m}$, as well as the presence of known OTUs affiliated with anaerobic methane oxidizers (Crenothrix, NC10) and an OTU affiliated with the anammox bacterium Candidatus "Anammoximicrobium" (Fig. 3c). The methane-oxidizing Crenothrix and NC10 OTUs showed peak abundance below the oxic-anoxic transition zone at $12-14 \mathrm{~m}$, whereas the anammox bacteria Candidatus Anammoximicrobium showed peak abundance 

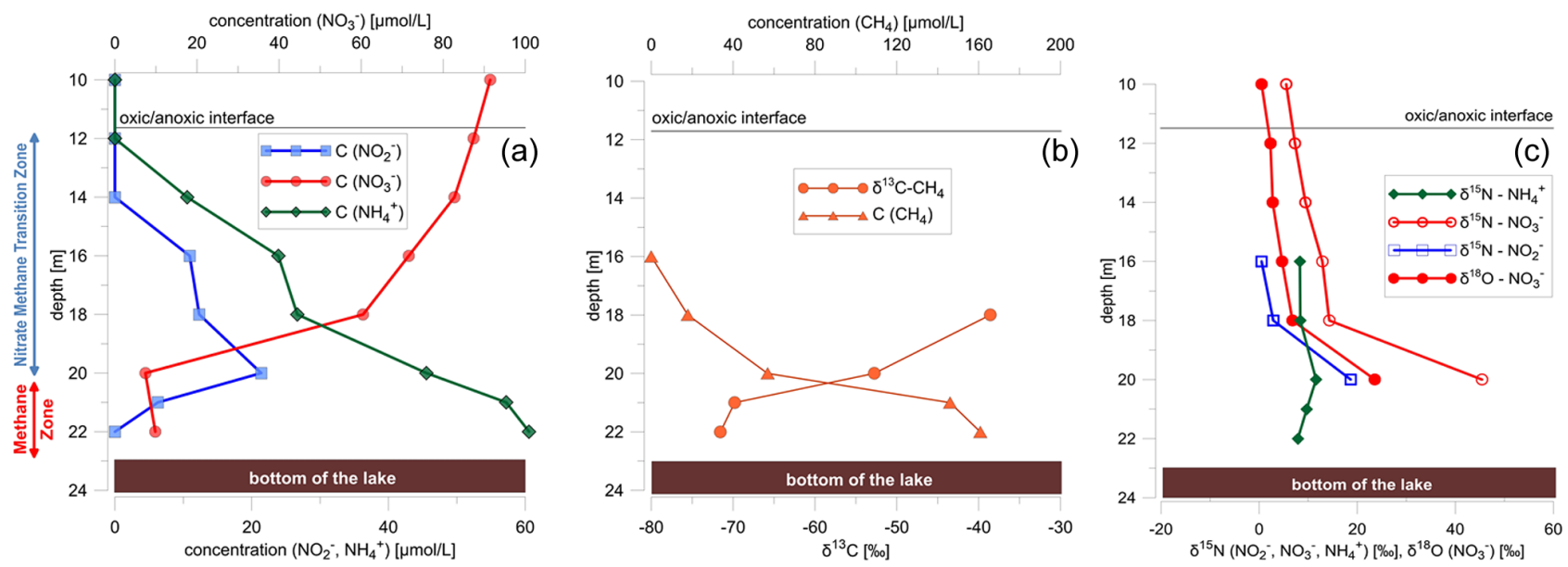

Figure 2. (a) Water column profiles below the oxycline (10 to $22 \mathrm{~m}$ ) for methane, nitrate, nitrite, and ammonium concentrations; (b) stableisotope data and concentration profile of methane $\left(\delta^{13} \mathrm{C}\right)$; and $(\mathbf{c})$ nitrate $\left(\delta^{15} \mathrm{~N}, \delta^{18} \mathrm{O}\right)$, nitrite $\left(\delta^{15} \mathrm{~N}\right)$, and ammonium $\left(\delta^{15} \mathrm{~N}_{\mathrm{NH}}\right)$ isotopes. $\delta^{15} \mathrm{~N}$ and $\delta^{18} \mathrm{O}$ values of nitrate were calculated by a mass-weighted isotope mass balance calculation using a $\delta^{18} \mathrm{O}$ value for nitrite of $+4 \%$ $\left(\delta^{18} \mathrm{O}\right.$ value of nitrite is from Casciotti et al., 2007).

in this zone and in the deeper water zone between 20 and $21 \mathrm{~m}$ (Fig. 3c).

\section{Discussion}

\subsection{Some evidence of AOM coupled with denitrification in the nitrate-methane transition zone (NMTZ)}

To test the hypothesis that methane diffusion from the lake sediments towards the oxycline (as opposed to microbially mediated AOM with nitrate reduction) can describe the observed depth profiles of methane in the water column, a simple 1-D diffusion model with a constant methane input $\left(C_{0}=\right.$ $0.16 \mathrm{mmol} \mathrm{L}^{-1}$ ) was applied (Fig. 4). The results indicated that diffusion processes alone are insufficient for explaining the nonlinear decrease of methane concentrations in the water column. Therefore, a model run that considers methane diffusion combined with degradation was performed. Results showed that a $k$ value of $0.03\left[\mathrm{~d}^{-1}\right]$ for methane oxidation in the hypolimnion represents a good fit between observed and modeled methane concentrations (Fig. 4). Interestingly, the results are in agreement with the results of Roland et al. (2017) for microbially mediated AOM with nitrate $\left(k \sim 0.07\left[\mathrm{~d}^{-1}\right]\right)$ from a temperate lake during the summer period, whereas aerobic methane oxidation rate constants where generally about a factor of 10 higher. However, because the oxic-anoxic transition zone is in close proximity to the nitrate reduction zone, numerical modeling studies are required that link the stable-isotope ratio and concentration profiles of methane to study the effect of micro-aerobic methane oxidation near the oxycline at Fohnsee (Fig. 4).

The vertical distribution of electron acceptors in the water column of Fohnsee was in agreement with the expected order of decreasing free-energy yields (Appelo and Postma,
2005). Nitrate concentrations decreased in the water column at a depth below $12 \mathrm{~m}$, where model results suggest that dissolved $\mathrm{O}_{2}$ was available at most in trace amounts (Fig. 1b). Sulfate concentrations of around $0.1 \mathrm{mmol} \mathrm{L}^{-1}$ remained unchanged throughout the water column in the presence of nitrate. Near the water-sediment interface sulfate concentrations decreased slightly (Fig. 1a). Decreasing sulfate concentrations at the bottom of the lake and nitrate concentrations at the same water depth of less than $0.015 \mathrm{mmolL}^{-1}$ can be thermodynamically explained by partial bacterial sulfate reduction at low sulfate concentrations in lake sediments (Vuillemin et al., 2018) and in micro-environments of particles near the lake sediment surface (Bianchi et al., 2028), or by mixing effects between sulfate-free water from the sediments, where methanogenesis may occur, and sulfatecontaining lake water.

Decreasing nitrate concentrations in the water column indicate microbial nitrate reduction in the anoxic water column of the lake coupled with the oxidation of DOC (heterotrophic denitrification) or methane (n-damo) that are both present in Fohnsee water (Figs. 1 and 2b). Stable-isotope data were used to test the hypothesis that denitrification occurred in zones where methane concentrations decreased. Methane is formed by methanogenesis in the sediments (Conrad et al., 2007; Norði et al., 2013) and diffuses upwards toward the oxycline. The $\delta^{13} \mathrm{C}$ value of $-71.6 \%$ for dissolved methane at the bottom of Fohnsee (Fig. 2b) indicates a biogenic source (Norði et al., 2013; Rudd and Hamilton, 1978). In the absence of dissolved oxygen $\left(<0.625 \mu \mathrm{molL}^{-1}\right)$, methane concentrations decreased and $\delta^{13} \mathrm{C}$ values of methane increased to values of $-38.6 \%$ o toward the oxycline (Fig. $2 b$ ), providing some evidence for AOM. At this depth interval, nitrate concentrations also decreased and $\delta^{15} \mathrm{~N}$ and $\delta^{18} \mathrm{O}$ values of nitrate increased from around 7 to $45 \%$ and from around 
(a)

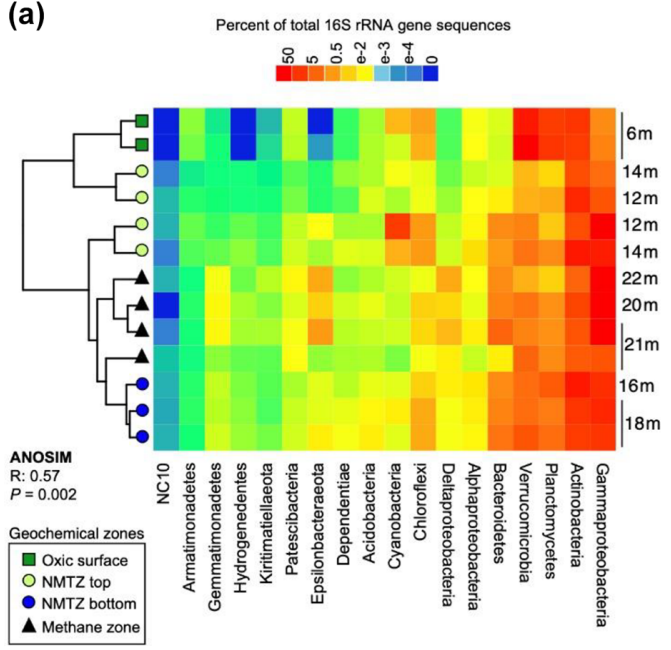

(b)
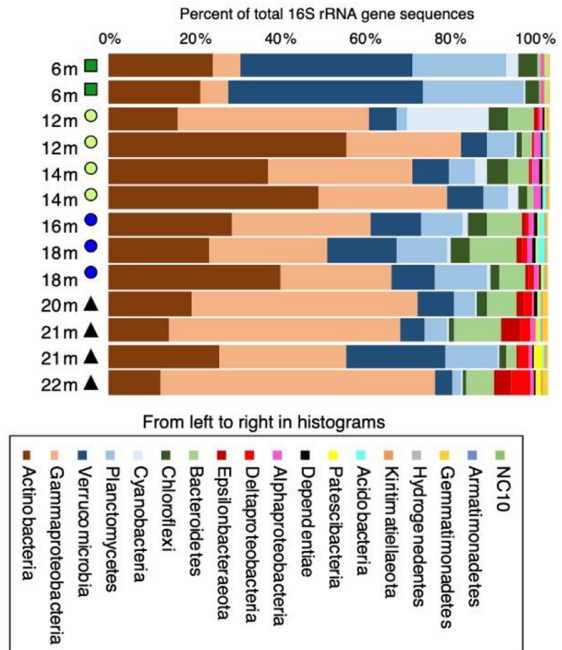

(c)

$16 S$ rRNA gene copies $\mathrm{mL}$

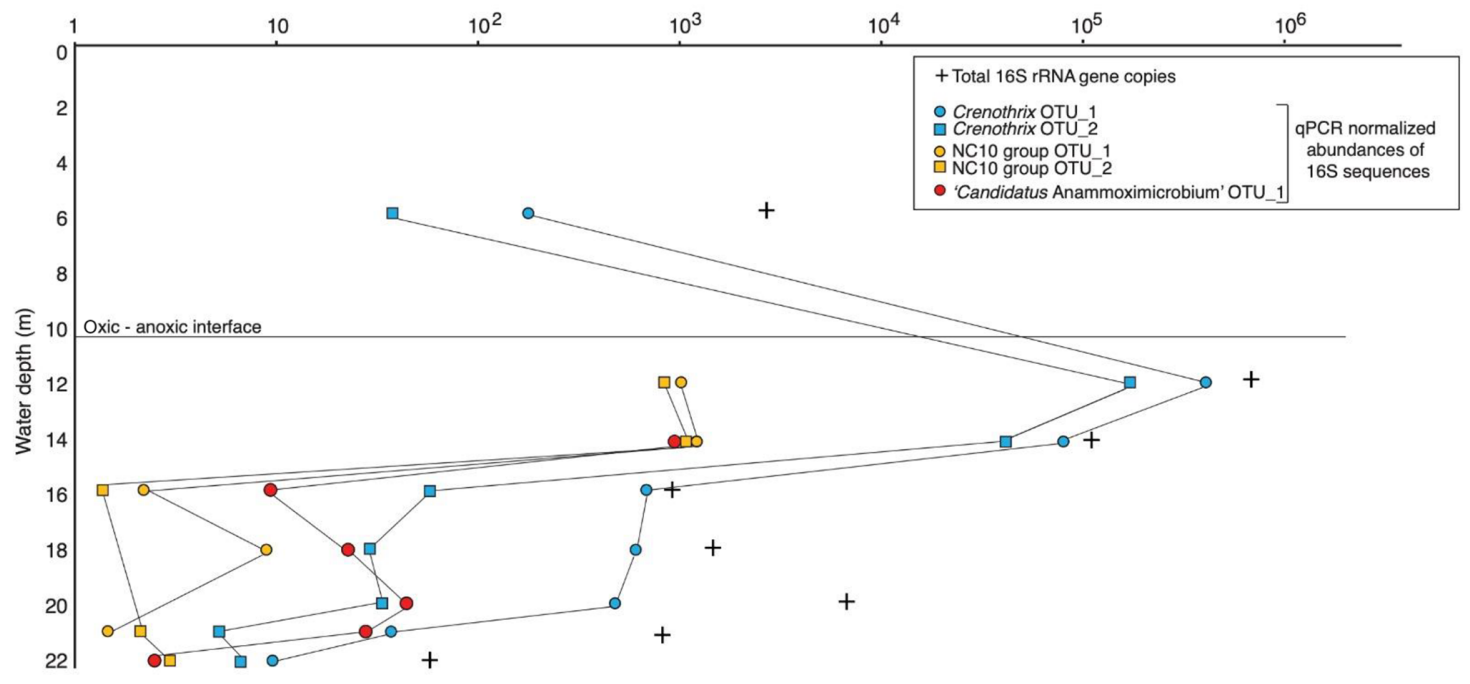

Figure 3. Analysis of 16S rRNA gene data from microbial communities in the stratified lake. (a) Heatmap showing the relative abundance of specific groups in the 16S rRNA gene sequencing data, and corresponding hierarchical clustering analysis (analysis of similarity (ANOSIM) $P$ value $=0.002)$ of four geochemically defined zones. For depths where replicates were obtained, the data for both replicates are shown. (b) The relative abundance of $16 \mathrm{~S}$ rRNA gene sequences affiliated with the major groups across the stratified water column. (c) Abundance of 16S rRNA gene copies determined via qPCR, and the qPCR normalized absolute abundances of 16S rRNA gene sequence relative abundances from key populations (OTUs) potentially involved in AOM and anammox, specifically those affiliated with Crenothrix, NC10, and potential anammox bacteria.

2 to $24 \%$ (Fig. 2c), respectively, while nitrite concentrations peaked (Fig. 1b). This provides clear evidence that denitrification was occurring in the water column, and the chemical and isotopic data demonstrate that some of the denitrification was coupled with microbial AOM (n-damo) in the NMTZ at a water depth between 16 and $20 \mathrm{~m}$. However, on the basis of our isotope data we cannot exclude that denitrification is coupled to the common anaerobic heterotrophic nitrate reduction, and methane oxidation is also affected by trace amounts of oxygen in suboxic waters, as shown by Blees et al. (2014) for Lake Lugano.

\subsection{Some evidence of anammox at the bottom of the NMTZ}

Several lines of qualitative and quantitative evidence indicate the co-occurrence of anammox, denitrification, and AOM towards the bottom of the NMTZ. As expected the nitrite concentration at a water depth of $20 \mathrm{~m}$ was highest where nitrate reduction occurred (Fig. 2a). Between this depth and the lake bottom, our data strongly suggest that anammox is the main sink of $\mathrm{NH}_{4}^{+}$. Ammonium occurs in concentrations of up to $0.06 \mathrm{mmolL}^{-1}$ at the bottom of the water column 


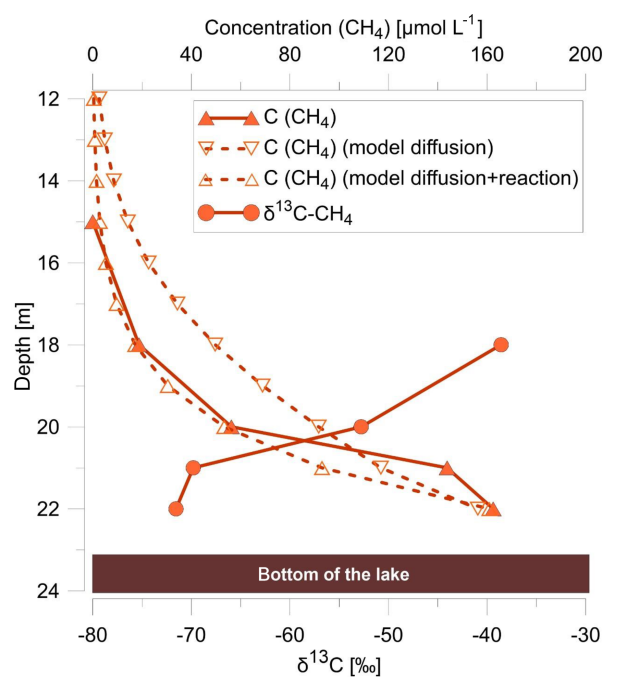

Figure 4. Depth profiles of methane concentration (filled triangles) and its isotopic composition (filled circles) within the water column, modeled methane concentrations (open triangles) using a 1-D diffusion model with a turbulent diffusion coefficient for $K_{z} \mathrm{CH} 4$ of $0.1 \mathrm{~m}^{2} \mathrm{~d}^{-1}$ (model diffusion), and a 1-D diffusion model additionally linked with a degradation term (first-order rate constant $k=0.03 \mathrm{~d}^{-1}$ ) (model diffusion and reaction).

at $22 \mathrm{~m}$, likely stemming from the heterotrophic degradation of organic nitrogen (e.g., proteins and amino acids) close to the sediment-water interface, and is subsequently transported from the methane zone near the lake sediments into the overlying water column (Norði et al., 2013; Wenk et al., 2014), where the $\mathrm{NH}_{4}^{+}$concentration decreases continually towards $<0.005 \mathrm{mmol} \mathrm{L}^{-1}$ at $12 \mathrm{~m}$ depth. The decrease in ammonium concentration with decreasing water depth is accompanied by an enrichment of ${ }^{15} \mathrm{~N}$ in the remaining ammonium shifting the $\delta^{15} \mathrm{~N}_{\mathrm{NH} 4}$ values from 7.9 to $11.6 \%$ between 22 and $20 \mathrm{~m}$ water depth (Fig. 2c), suggesting that ammonium is oxidized anaerobically while enriching the remaining substrate in ${ }^{15} \mathrm{~N}$.

To explain the moderate isotopic shift of $4 \%$ in $\delta^{15} \mathrm{~N}$ of ammonium, Wunderlich et al. (2018) suggested a transport limitation model, where small nitrogen isotope fractionation during denitrification can be explained. Briefly, a partial transport limitation of nitrate into the cell in relation to nitrate reduction would shift the apparent kinetic isotope effect during denitrification towards a value of unity. Similar processes could be assumed for ammonium oxidation during anammox at Fohnsee. As dissolved ammonium concentrations are very low and probably diffusion-controlled, ammonium uptake may represent the rate-limiting step, and nitrogen isotope fractionation may be low compared to values observed by Brunner et al. (2013) in laboratory studies where equilibrium conditions can be assumed. Wenk et al. (2014) also found a small isotopic shift in nitrogen of around $8 \%$ o for anammox at Lake Lugano when almost all ammonium was oxidized and suggested a similar isotope model for the observed low nitrogen isotope fractionation during anammox.

Above a water depth of $20 \mathrm{~m}$ there is no isotopic evidence that ammonium is oxidized under anaerobic conditions, and the decrease of ammonium concentrations may be affected by diffusion and by ammonification and nitrification processes that may occur at the oxycline. We observed a difference of $\delta^{15} \mathrm{~N}$ values $\left(\Delta \delta^{15} \mathrm{~N}\right)$ of nitrate and nitrite of around $11 \%$ in the NMTZ at depths of 16 and $18 \mathrm{~m}$, where we suggest the microbial linkage of AOM and denitrification maybe via n-damo. But again, it is also possible that some of the denitrification is coupled to heterotrophic nitrate and nitrite reduction in the water column, as the numerically dominant bacteria found throughout the water column were the Gammaproteobacteria, many of which are facultative anaerobes that perform heterotrophic nitrate reduction. When new nitrate is formed as metabolic product by nitrite oxidation during anammox, the $\delta^{15} \mathrm{~N}$ value of the newly formed nitrate is affected by an inverse isotope effect (preferential removal of ${ }^{15} \mathrm{~N}$ from the nitrite pool during oxidation to nitrate), resulting in nitrate that is strongly enriched in ${ }^{15} \mathrm{~N}$ (Brunner et al., 2013). In this study the difference between $\delta^{15} \mathrm{~N}$ values of nitrate and nitrite $\left(\Delta \delta^{15} \mathrm{~N}\right)$ increased from $11 \%$ in NMTZ to $>26 \%$ at a water depth of $20 \mathrm{~m}$, where $\delta^{15} \mathrm{~N}$ values of ammonium increased while $\mathrm{NH}_{4}^{+}$concentrations decreased (Fig. 2c). This is consistent with the additional isotopic difference in $\delta^{15} \mathrm{~N}$ values between nitrate and nitrite of around $+15 \%$ arising as the result of production of highly ${ }^{15} \mathrm{~N}$-enriched nitrate deriving from anammox $\left(\Delta \delta^{15} \mathrm{~N}\right.$ of $+31 \%$ o). The reason for the observed small isotopic differences between nitrite and nitrate $\left(\Delta \delta^{15} \mathrm{~N}\right)$ during the anammox process within this study $\left(\Delta \delta^{15} \mathrm{~N}\right.$ of $+26 \%$ ) compared to the results $\left(\Delta \delta^{15} \mathrm{~N}\right.$ of $+31 \%$ ) found in a laboratory experiment (Brunner et al., 2013) could be the result of different anammox strains in lake water and the microcosm experiment, limiting environmental concentrations of nitrite, or that the suggested inverse isotope effect by anammox was superimposed on "normal" isotope effects during denitrification in the lake water at a water depth of $20 \mathrm{~m}$.

Furthermore, the deviation of the slope of $\delta^{18} \mathrm{O}$ vs. $\delta^{15} \mathrm{~N}$ values on a dual isotope plot (2-D plot) for nitrate from the expected value of 1 for microbial denitrification (Knöller et al., 2011; Wunderlich et al., 2012) can be used to identify anammox. Granger and Wankel (2016) used a modeling approach linked with $\mathrm{pH}$-dependent isotope exchange reactions between water-oxygen and nitrite-oxygen (Buchwald and Casciotti, 2010; Casciotti et al., 2007, 2010) to demonstrate that in a $\delta^{18} \mathrm{O}$ vs. $\delta^{15} \mathrm{~N}$ plot for nitrate a slope lower than 1 is a powerful indicator for the occurrence of anammox in an anoxic environment. During anammox, when nitrite is reduced with ammonium as an electron donor and nitrate is produced, one oxygen atom from water having a $\delta^{18} \mathrm{O}$ value of around $-10 \% \mathrm{o}$ is incorporated into the newly formed nitrate. This incorporation of a new $\mathrm{O}$ atom is also most likely associated with a kinetic isotope effect - as has 


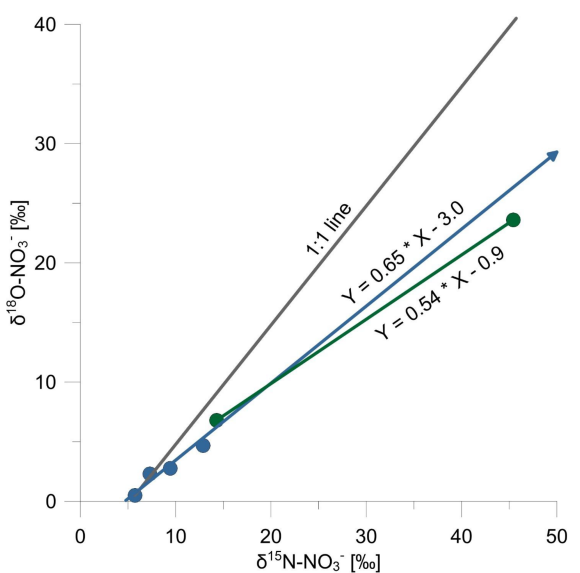

Figure 5. $\delta^{18} \mathrm{O}$ vs. $\delta^{15} \mathrm{~N}$ plot of nitrate with the typical trajectory of 1 for denitrification obtained under laboratory conditions (black line), calculated trajectory of 0.65 for the n-damo zone $(20 \mathrm{~m}$ and above, blue line) and around 0.5 for the anammox zone (20-22 m, green line).

been demonstrated for nitrite-oxidizing bacteria (see Buchwald and Casciotti, 2010) (Fig. 2c). As a result, the anammox process leads to $\delta^{18} \mathrm{O}$ values of nitrate remaining low, while $\delta^{15} \mathrm{~N}$ of the remaining nitrate is affected by an inverse nitrogen isotope effect and values continue to increase. The $\delta^{18} \mathrm{O}$ vs. $\delta^{15} \mathrm{~N}$ plot for nitrate samples from depths between 20 and $22 \mathrm{~m}$ in our study displays a slope of 0.5 , while the slope was 0.65 in the NMTZ between 20 and $12 \mathrm{~m}$, much closer to the typical trajectory for denitrification of $\sim 1$ obtained under laboratory experiments (Fig. 5). The much slower slope of 0.5 on the $\delta^{18} \mathrm{O}$ vs. $\delta^{15} \mathrm{~N}$ plot for nitrate is an additional line of evidence that strongly suggests that anammox occurred at the bottom of the NMTZ between 20 and $21 \mathrm{~m}$.

\subsection{Crenothrix, NC10, anammox, and heterotrophic bacteria in the water column of Fohnsee}

We identified Gammaproteobacterial methane-oxidizing bacteria related to Crenothrix that reach their peak abundance particularly in the NMTZ of the water column of the lake (between 12 and $20 \mathrm{~m}$ ). The abundance of Crenothrix rRNA gene copies reaches up to $10^{5}$ (Fig. 3b), which is 23 orders of magnitude higher than the biomass reported for Crenothrix in the Swiss Alpine Rotsee and Lake Zug (Kits et al., 2015; Oswald et al., 2017), where they may act as denitrifying methanotrophs that also have the capability for aerobic metabolism. The facultative metabolism of Crenothrix likely allows them to adapt to changing environmental conditions, supporting any nitrate-reducing ANME-2d (with lower doubling times) in the denitrification zone of stratified lakes (Deutzmann et al., 2014). We did not detect any representatives of the ANME- $2 \mathrm{~d}$ in our $16 \mathrm{~S}$ dataset - despite relatively deep sequencing depth ( $>150000$ reads per sample), indicating that, if they were in the lake water, they were at abun- dances below our detection limit. ANME-2d may, therefore, be major contributors to AOM in bioreactor studies (Haroon et al., 2013; Shen and $\mathrm{Hu}, 2012$ ) and sediments, but not in the water column of this lake.

The presence of two separate populations of NC10 bacteria at a water depth between 12 and $22 \mathrm{~m}$, in the region where anaerobic oxidation of methane linked with denitrification also exists, may suggest that this organism was also partially contributing to the anaerobic oxidation of methane with nitrite (n-damo). However, it remains unclear whether Crenothrix, which also peaked in this region, completely reduced dissolved nitrate to $\mathrm{N}_{2}$ or whether both $\mathrm{NC10}$ bacteria ( $\mathrm{NO}_{2}^{-}$reduction) and Crenothrix are involved in the $\mathrm{N}$ loss processes in a portion of the water column. In this context it is also worth mentioning that the highest abundance of NC10 bacteria in our and other studies is often observed at the oxicanoxic interface (Ettwig et al., 2008), and it is controversially discussed whether $\mathrm{Ca}$. M. oxyfera can also use external $\mathrm{O}_{2}$ to oxidize methane near the oxycline. Therefore, the respective roles of NC10 and Crenothrix in nitrite reduction and nitrate reduction, respectively, linked with AOM remains unclear in this study.

Within the anoxic regions of the water column (NMTZ and methane zone), the OTU affiliated with Candidatus Anammoximicrobium is ubiquitous (Fig. 3b), and its lack of detection in the oxic zone indicates that it is a strict anaerobe. Candidatus Anammoximicrobium is an aggregate-forming bacterium corresponding to a new genus within the Planctomycetes that is capable of anaerobically oxidizing ammonium with nitrite and has been previously found to carry out anammox in a wastewater bioreactor (Khramenkov et al., 2013). The Candidatus Anammoximicrobium and NC10 bacteria both utilize nitrite as a terminal electron acceptor, and they co-occur at a depth of $20 \mathrm{~m}$, where highest nitrite concentrations were observed (Fig. 2b). While activity indicators such as transcriptomes or NanoSIMS are needed to prove the anammox activity of Candidatus Anammoximicrobium in our samples, the stable isotope and geochemical profiles indicate that this OTU is present in a geochemical setting where anammox may take place. This, together with its affiliation to Candidatus Anammoximicrobium, indicates that this OTU has the potential to perform anammox in the aquatic environment of Fohnsee at a depth of $20 \mathrm{~m}$. At the water depth where nitrite was available due to denitrification via anaerobic methane oxidation, both anammox and NC10 bacteria could compete for the same available nitrite as speculated for Crenothrix and NC10 bacteria in the NMTZ as shown in Fig. 6.

As heterotrophic denitrification is a common process in freshwater ecosystems that have abundant organic matter, it is likely that heterotrophy was also responsible for some of the observed consumption of nitrate. Because nitrate and nitrite reduction is such a widespread trait possessed by many facultative anaerobic bacteria, it is not possible to use our $16 \mathrm{~S}$ rRNA gene sequence data to specifically 


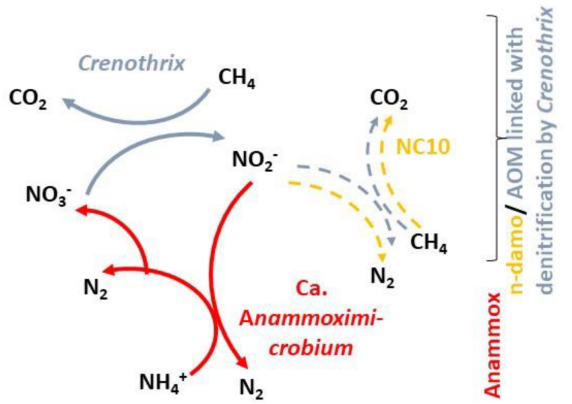

Figure 6. Conceptual model of the coupled $\mathrm{N}$ and $\mathrm{C}$ cycles in the anoxic water column of Fohnsee.

show the abundance of heterotrophic nitrate and nitrite reducers. However, microbes belonging to the Gammaproteobacteria class are very abundant in our samples, and, in addition to the methane-oxidizing genus Crenothrix, they are well known to consist of many species that are capable of heterotrophic nitrate and nitrite reduction, a trait that is widespread throughout the Gammaproteobacteria class. The relative abundance of Gammaproteobacteria increases with depth into the anoxic zone (Fig. 3b), and, in addition to methane-oxidizing Crenothrix, there are many other heterotrophic Gammaproteobacteria groups, including the genera Pseudomonas, Acidovorax, and Alteromonas. Thus, some of the other Gammaproteobacteria that gradually accumulated in deeper waters of the lake (Fig. 3b) are heterotrophs that, in addition to Crenothrix, may have performed nitrate and nitrite reduction, and denitrification.

The detected microorganisms at Fohnsee were found to be ecologically important in driving the $\mathrm{C}$ and $\mathrm{N}$ cycles of other stratified lakes and freshwater reservoirs (Deutzmann et al., 2014; Naqvi et al., 2018; Oswald et al., 2017). This makes it highly likely that these microbial groups are also potentially responsible for the removal of nitrogen and methane at Fohnsee.

\section{Conclusions}

While aerobic methane oxidation in lake water has been known to occur for over a century, knowledge of anammox and AOM coupled with denitrification in natural anoxic environments within stratified lakes is scarce. Our field study results show that AOM, denitrification, and anammox may cooccur in the anoxic water column of the stratified Fohnsee. This provides a natural environmental context from a seasonally stratified lake, which supports previous bioreactor studies that showed a coupling of n-damo and anammox under more controlled conditions (Haroon et al., 2013). The linkage of the $\mathrm{N}$ and $\mathrm{C}$ cycles that we have observed in the stratified waters of Fohnsee could be an important process in stratified lakes contributing to the removal of nitrogen and methane from freshwater ecosystems.
Sample availability. Illumina sequencing data for community analyses are deposited at NCBI BioSample (http://www.ncbi.nlm.nih. gov/biosample, last access: 19 October 2020) under accession number PRJNA541816.

Author contributions. FE designed the study. AW performed the field work and the measurements of stable water isotopes. Instrumentation and methodology were provided by MS for $\mathrm{N}$ isotopes and $\mathrm{BM}$ for $\mathrm{CH}_{4}$. FE performed the modeling study. ÖKC and WDO performed the qPCR. WDO interpreted the data. FE, AW, $\mathrm{BM}, \mathrm{MS}$, and WDO discussed the results. FE wrote the original manuscript, supported by BM and WDO. AW visualized the isotope and water chemistry data.

Competing interests. The authors declare that they have no conflict of interest.

Acknowledgements. We thank Susanne Thiemann for technical assistance and the staff of the Research Station Iffeldorf for the support during fieldwork. Thanks to two anonymous reviewers for their excellent comments and suggestions on an earlier version of the manuscript.

Financial support. This research has been supported by the Deutsche Forschungsgemeinschaft (grant no. EI 401/10-1) to Florian Einsiedl and by a NSERC discovery grant to Bernhard Mayer.

This work was supported by the German Research Foundation (DFG) and the Technical University of Munich (TUM) in the framework of the Open Access Publishing Program.

Review statement. This paper was edited by Caroline P. Slomp and reviewed by two anonymous referees.

\section{References}

Appelo, C. A. J. and Postma, D.: Geochemistry Groundwater and Pollution, 2nd Edn., Dutch, Balkema Publ., 415 pp., 2005.

Bastviken, D., Cole, J., Pace, M., and Tranvik, L.: Methane emissions from lakes: Dependence of lake characteristics, two regional assessments, and a global estimate, Global Biogeochem. Cy., 18, GB4009 https://doi.org/10.1029/2004GB002238, 2004.

Blees, J., Niemann, H., Wenk, C. B., Zopfi, J., Schubert, C. J., Kirf, M. K., Veronesi, M. L., Hitz, C., and Lehmann, M. F. Micro-aerobic bacterial methane oxidation in the chemocline and anoxic water column of deep south-Alpine Lake Lugano (Switzerland), Limnol. Oceanogr., 59, 311-324, 2014.

Borrel, G., Jézéquel, D., Biderre-Petit, C., Morel-Desrosiers, N., Morel, J.-P., Peyret, P., Fonty, G., and Lehours, A.-C.: Production and consumption of methane in freshwater lake ecosystems, Res. Microbiol., 162, 832-847, 2011. 
Braig, E., Welzl, G., STichler, W., Raeder, U., and Melzer, A.: Entrainment, annual circulation and groundwater inflow in a chain of lakes as inferred by stable ${ }^{18} \mathrm{O}$ isotopic signatures in the water column, J. Limnol., 69, 278-286. https://doi.org/10.4081/jlimnol.2010.278, 2010.

Brielmann, H., Griebler, C., Schmidt, S. I., Michel, R., and Lueders, T.: Effects of thermal energy discharge on shallow groundwater ecosystems, FEMS Microbiol. Ecol., 68, 273-286, 2009.

Brunner, B., Contreras, S., Lehmann, M. F., Matantseva, O., Rollog, M., Kalvelage, T., Klockgether, G., Lavik, G., Jetten, M. S. M., Kartal, B., and Kuypers, M. M. M.: Nitrogen isotope effects induced by anammox bacteria, P. Natl. Acad. Sci. USA, 110, 18994-18999, 2013.

Buchwald, C. and Casciotti, K. L.: Oxygen isotopic fractionation and exchange during bacterial nitrite oxidation, Limnol. Oceanogr., 55, 1064-1074, 2010.

Casciotti, K. L., Böhlke, J. K., McIlvin, M. R., Mroczkowski, S. J., and Hannon, J. E.: Oxygen Isotopes in Nitrite: Analysis, Calibration, and Equilibration, Anal. Chem., 79, 2427-2436, 2007.

Casciotti, K. L., McIlvin, M., and Buchwald, C.: Oxygen isotopic exchange and fractionation during bacterial ammonia oxidation, Limnol. Oceanogr., 55, 753-762, 2010.

Conrad, R., Chan, O.-C., Claus, P., and Casper, P.: Characterization of methanogenic Archaea and stable isotope fractionation during methane production in the profundal sediment of an oligotrophic lake (Lake Stechlin, Germany), Limnol. Oceanogr., 52, 1393 1406, 2007.

Coskun, O. K., Pichler, M., Vargas, S., Gilder, S., and Orsi, W. D.: Linking Uncultivated Microbial Populations and Benthic Carbon Turnover by Using Quantitative Stable Isotope Probing, Appl. Environ. Microb., 84, https://doi.org/10.1128/AEM.01083-18, 2018.

Crank, J.: The Mathematics of Diffusion, 2nd Edn., Oxford University Press, London, 69-88, 1975.

Deutzmann, J. S., Stief, P., Brandes, J., and Schink, B.: Anaerobic methane oxidation coupled to denitrification is the dominant methane sink in a deep lake, P. Natl. Acad. Sci. USA, 111, 18273-18278, 2014

Edgar, R. C.: UPARSE: highly accurate OTU sequences from microbial amplicon reads, Nat. Methods, 10, 996-998, 2013.

Eller, G., Känel, L., and Krüger, M.: Cooccurrence of Aerobic and Anaerobic Methane Oxidation in the Water Column of Lake Plußsee, Appl. Environ. Microb., 71, 8925-8928, 2005.

EPA: Technical guidance for the natural attenuation indicators: methane, ethane, and ethene analysis guidance, revision 1. US EPA, Region 1, Boston, MA, USA, 2002.

Ettwig, K. F., Shima, S., Van De Pas-Schoonen, K. T., Kahnt, J., Medema, M. H., Op Den Camp, H. J. M., Jetten, M. S. M., and Strous, M.: Denitrifying bacteria anaerobically oxidize methane in the absence of Archaea, Environ. Microbiol., 10, 3164-3173, 2008.

Ettwig, K. F., Butler, M. K., Le Paslier, D., Pelletier, E., Mangenot, S., Kuypers, M. M. M., Schreiber, F., Dutilh, B. E., Zedelius, J., de Beer, D., Gloerich, J., Wessels, H. J. C.T., van Alen, T., Luesken, F., Wu, M. L., van de Pas-Schoonen, K. T., Op den Camp, H. J. M., Janssen-Megens, E. M., Francoijs, K.J., Stunnenberg, H., Weissenbach, J., Jetten, M. S. M., and Strous, M.: Nitrite-driven anaerobic methane oxidation by oxygenic bacteria, Nature, 464, 543-548, 2010.
Feisthauer, S., Vogt, C., Modrzynski, J., Szlenkier, M., Krüger, M., Siegert, M., and Richnow, H.-H.: Different types of methane monooxygenases produce similar carbon and hydrogen isotope fractionation patterns during methane oxidation, Geochim. Cosmochim. Ac., 75, 1173-1184, 2011.

Fuex, A. N.: Experimental evidence against an appreciableisotopic fractionation of methane during migration, in: Advances in Organic Geochemistry, edited by: Douglas, A. G. and Maxwell, J. R., 1979, Pergamon Press, Oxford, 725-732, 1980.

Francis, C. A., Beman, J. M., and Kuypers, M. M. M.: New processes and players in the nitrogen cycle: the microbial ecology of anaerobic and archaeal ammonia oxidation, Isme J., 1, 19-27, https://doi.org/10.1038/ismej.2007.8, 2007.

Granger, J. and Wankel, S. D.: Isotopic overprinting of nitrification on denitrification as a ubiquitous and unifying feature of environmental nitrogen cycling, P. Natl. Acad. Sci. USA, 113, E6391E6400, 2016.

Haroon, M. F., Hu, S., Shi, Y., Imelfort, M., Keller, J., Hugenholtz, P., Yuan, Z., and Tyson, G. W.: Anaerobic oxidation of methane coupled to nitrate reduction in a novel archaeal lineage, Nature, 500, 567-570, https://doi.org/10.1038/nature12375, 2013.

Hu, S., Zeng, R. J., Haroon, M. F., Keller, J., Lant, P. A., Tyson, G. W., and Yuan, Z.: A laboratory investigation of interactions between denitrifying anaerobic methane oxidation (DAMO) and anammox processes in anoxic environments, Sci. Rep., 5, 8706, https://doi.org/10.1038/srep08706, 2015.

IPCC Working Group I: Climate Change 2001: The Scientific Basis, Cambridge University Press, Cambridge, 2001.

Khramenkov, S. V., Kozlov, M. N., Krevbona, M. V., Drofeev, A. G., Kazakova, E. A., Grachev, V. A., Kuznetsov, B. B., Poliakov, D., and Nikolaev Iu, A.: A novel bacterium carrying out anaerobic ammonium oxidation in a reactor for biological treatment of the filtrate of wastewater fermented residue, Mikrobiologiia, 82, 625-634, 2013.

Kits, K. D., Campbell, D. J., Rosana, A. R., and Stein, L. Y.: Diverse electron sources support denitrification under hypoxia in the obligate methanotroph Methylomicrobium album strain BG8, Front. Microbiol., 6, 1072, https://doi.org/10.3389/fmicb.2015.01072, 2015.

Knöller, K., Vogt, C., Haupt, M., Feisthauer, S., and Richnow, H. Experimental investigation of nitrogen and oxygen isotope fractionation in nitrate and nitrite during denitrification, Biogeochemistry, 103, 371-384, https://doi.org/10.1007/s10533-0109483-9, 2011.

Kojima, H., Tsutsumi, M., Ishikawa, K., Iwata, T., Mußmann, M., and Fukui, M.: Distribution of putative denitrifying methane oxidizing bacteria in sediment of a freshwater lake, Lake Biwa, Syst Appl. Microbiol., 35, 233-238, 2012.

Kozich, J. J., Westcott, S. L., Baxter, N. T., Highlander, S. K., and Schloss, P. D.: Development of a Dual-Index Sequencing Strategy and Curation Pipeline for Analyzing Amplicon Sequence Data on the MiSeq Illumina Sequencing Platform, Appl. Environ. Microb., 79, 5112-5120, 2013.

Kuypers, M. M. M., Sliekers, A. O., Lavik, G., Schmid, M., Jørgensen, B. B., Kuenen, J. G., Sinninghe Damsté, J. S., Strous, M., and Jetten, M. S. M.: Anaerobic ammonium oxidation by anammox bacteria in the Black Sea, Nature, 422, 608-611, 2003. 
Luesken, F. A., Sánchez, J., van Alen, T. A., Sanabria, J., Op den Camp, H. J. M., Jetten, M. S. M., and Kartal, B.: Simultaneous Nitrite-Dependent Anaerobic Methane and Ammonium Oxidation Processes, Appl. Environ. Microb., 77, 6802-6807, 2011.

McIlvin, M. R. and Altabet, M. A.: Chemical Conversion of Nitrate and Nitrite to Nitrous Oxide for Nitrogen and Oxygen Isotopic Analysis in Freshwater and Seawater, Anal, Chem., 77, 5589$5595,2005$.

Mulder, A., van de Graaf, A. A., Robertson, L. A., and Kuenen, J. G.: Anaerobic ammonium oxidation discovered in a denitrifying fluidized bed reactor, FEMS Microbiol. Ecol., 16, 177$183,1995$.

Naqvi, S. W. A., Lam, P., Narvenkar, G., Sarkar, A., Naik, H., Pratihary, A., Shenoy, D. M., Gauns, M., Kurian, S., Damare, S., Duret, M., Lavik, G., and Kuypers, M. M. M.: Methane stimulates massive nitrogen loss from freshwater reservoirs in India, Nat. Commun., 9, 1265, https://doi.org/10.1038/s41467018-03607-z, 2018.

Norði, K. à., Thamdrup, B., and Schubert, C. J.: Anaerobic oxidation of methane in an iron-rich Danish freshwater lake sediment, Limnol. Oceanogr., 58, 546-554, 2013.

Oswald, K., Milucka, J., Brand, A., Littmann, S., Wehrli, B., Kuypers, M. M. M., and Schubert, C. J.: Light-Dependent Aerobic Methane Oxidation Reduces Methane Emissions from Seasonally Stratified Lakes, PLoS ONE 10, e0132574, https://doi.org/10.1371/journal.pone.0132574, 2015.

Oswald, K., Graf, J. S., Littmann, S., Tienken, D., Brand, A., Wehrli, B., Albertsen, M., Daims, H., Wagner, M., Kuypers, M. M. M., Schubert, C. J., and Milucka, J.: Crenothrix are major methane consumers in stratified lakes, Isme J., 11, 2124-2140, https://doi.org/10.1038/ismej.2017.77, 2017.

Parada, A. E., Needham, D. M., and Fuhrman, J. A.: Every base matters: assessing small subunit rRNA primers for marine microbiomes with mock communities, time series and global field samples, Environ. Microbiol., 18, 1403-1414, 2016.

Pichler, M., Coskun, O. K., Ortega-Arbulu, A. S., Conci, N., Worheide, G., Vargas, S., and Orsi, W. D.: A 16S rRNA gene sequencing and analysis protocol for the Illumina MiniSeq platform, MicrobiologyOpen, 7, e611, https://doi.org/10.1002/mbo3.611, 2018.

Raghoebarsing, A. A., Pol, A., van de Pas-Schoonen, K. T., Smolders, A. J. P., Ettwig, K. F., Rijpstra, W. I. C., Schouten, S., Damsté, J. S. S., Op den Camp, H. J. M., Jetten, M. S. M., and Strous, M.: A microbial consortium couples anaerobic methane oxidation to denitrification, Nature, 440, 918-921, https://doi.org/10.1038/nature04617, 2006.

Roland F. A. E., Darchambeau F., Morana C., Bouillon S., and Borges A. V.: Emission and oxidation of methane in a meromictic, eutrophic and temperate lake (Dendre, Belgium), Chemosphere, 168, 756-764, https://doi.org/10.1016/j.chemosphere.2016.10.138, 2017.

Rudd, J. W. M. and Hamilton, R. D.: Methane cycling in a eutrophic shield lake and its effects on whole lake metabolism 1, Limnol. Oceanogr., 23, 337-348, 1978.

Sabrekov, A. F., Runkle, B. R. K., Glagolev, M. V., Terentieva, I. E., Stepanenko, V. M., Kotsyurbenko, O. R., Maksyutov, S. S., and Pokrovsky, O. S.: Variability in methane emissions from West Siberia's shallow boreal lakes on a regional scale and its environmental controls, Biogeosciences, 14, 3715-3742, https://doi.org/10.5194/bg-14-3715-2017, 2017.

Schubert, C. J., Durisch-Kaiser, E., Wehrli, B., Thamdrup, B., Lam, P., and Kuypers, M. M. M.: Anaerobic ammonium oxidation in a tropical freshwater system (Lake Tanganyika), Environ. Microbiol., 8, 1857-1863, 2006.

Semaoune, P., Sebilo, M., Templier, J., and Derenne, S.: Is there any isotopic fractionation of nitrate associated with diffusion and advection? Environ. Chem., 9, 158-162, 2012.

Shen, L.-d., Liu, S., Huang, Q., Lian, X., He, Z.-f., Geng, S., Jin, R.c., He, Y.-f., Lou, L.-p., Xu, X.-y., Zheng, P., and Hu, B.-1.: Evidence for the Cooccurrence of Nitrite-Dependent Anaerobic Ammonium and Methane Oxidation Processes in a Flooded Paddy Field, Appl. Environ. Microb., 80, 7611-7619, 2014.

Shen, L.-D. and Hu, B.-L.: Microbiology, ecology, and application of the nitrite-dependent anaerobic methane oxidation process, Front. Microbiol., 3, 269, https://doi.org/10.3389/fmicb.2012.00269, 2012.

Shi, Y., Hu, S., Lou, J., Lu, P., Keller, J., and Yuan, Z.: Nitrogen Removal from Wastewater by Coupling Anammox and MethaneDependent Denitrification in a Membrane Biofilm Reactor, Environ. Sci. Technol., 47, 11577-11583, 2013.

Strous, M. and Jetten, M. S. M.: Anaerobic Oxidation of Methane and Ammonium, Annu. Rev. Microbiol., 58, 99-117, 2004.

Thauer, R. K. and Shima, S.: Methane as fuel for anaerobic microorganisms, Ann. NY Acad. Sci., 1125, 158-170, 2008.

Vuillemin, A., Horn, F., Friese, A., W., Matthias; A., Mashal; W., Dirk; H. C., Orsi, W. D., Crowe, S. A., and Kallmeyer, J.: Metabolic potential of microbial communities from ferruginous sediments, Environ. Microbiol., 20, 4297-4313, 2018.

Wenk, C. B., Zopfi, J., Blees, J., Veronesi, M., Niemann, H., and Lehmann, M. F.: Community $\mathrm{N}$ and $\mathrm{O}$ isotope fractionation by sulfide-dependent denitrification and anammox in a stratified lacustrine water column, Geochim. Cosmochim. Ac. 125, 551563, 2013.

Wenk, C. B., Zopfi, J., Blees, J., Veronesi, M., Niemann, H., and Lehmann, M. F.: Community $\mathrm{N}$ and $\mathrm{O}$ isotope fractionation by sulfide-dependent denitrification and anammox in a stratified lacustrine water column, Geochim. Cosmochim. Ac., 125, 551563, 2014.

Wunderlich, A., Meckenstock, R., and Einsiedl, F.: Effect of Different Carbon Substrates on Nitrate Stable Isotope Fractionation During Microbial Denitrification, Environ. Sci. Technol., 46, 4861-4868, 2012.

Wunderlich, A., Heipieper, H. J., Elsner, M., and Einsiedl, F.: Solvent stress-induced changes in membrane fatty acid composition of denitrifying bacteria reduce the extent of nitrogen stable isotope fractionation during denitrification, Geochim. Cosmochim. Ac., 239, 275-283, 2018.

Zhang, L., Altabet, M. A., Wu, T., and Hadas, O.: Sensitive Measurement of $\mathrm{NH}_{4}^{+15} \mathrm{~N} /{ }^{14} \mathrm{~N}\left(\delta^{15} \mathrm{NH}_{4}^{+}\right)$at Natural Abundance Levels in Fresh and Saltwaters, Anal. Chem., 79, 5297-5303, 2007.

Zhu, G., Wang, S., Li, Y., Zhuang, L., Zhao, S., Wang, C., Kuypers, M. M. M., Jetten, M. S. M., and Zhu, Y.: Microbial pathways for nitrogen loss in an upland soil, Environ. Microbiol., 20, 1723-1738, 2018. 